\title{
Editorial
}

\section{Systems and Industries in Response to COVID-19 Crisis: Closing Remarks}

\author{
Shahryar Sorooshian 1,2 (D) \\ 1 Department of Business Administration, University of Gothenburg, 41124 Gothenburg, Sweden; \\ shahryar.sorooshian@gu.se \\ 2 Prime School of Logistics, Saito University College, Petaling Jaya 46200, Malaysia
}

Citation: Sorooshian, S. Systems and Industries in Response to COVID-19 Crisis: Closing Remarks. Appl. Syst. Innov. 2022, 5, 22. https://doi.org/ $10.3390 /$ asi5010022

Received: 17 October 2021

Accepted: 25 October 2021

Published: 7 February 2022

Publisher's Note: MDPI stays neutral with regard to jurisdictional claims in published maps and institutional affiliations.

Copyright: (C) 2022 by the author. Licensee MDPI, Basel, Switzerland. This article is an open access article distributed under the terms and conditions of the Creative Commons Attribution (CC BY) license (https:// creativecommons.org/licenses/by/ $4.0 /)$.

\begin{abstract}
Many industries and systems have faced consequences as a result of the COVID-19 outbreak In this time, we are happy to had the publication of a Special Issue of Applied System Innovation titled "Systems and Industries in Response to the COVID-19 Crisis". This editorial article contains the special issue's closing remarks. However, while the scope of this given special issue grabbed the interest of practitioners and scholars, there is still much to be learned from COVID-19's experience. Thus, suggestions for future special issues are included with this letter.
\end{abstract}

Keywords: COVID-19; system; industry

\section{Editorial}

We are pleased to had a Special Issue of Applied System Innovation, titled "Systems and Industries in Response to COVID-19 Crisis". Hence with this editorial, the leading guest editor, on behalf of the team, is presenting the conclusion of the issue, together with thanking the personnel and academic editorial board of the Applied System Innovation, as well as reviewers and authors who have contributed to this special issue.

Due to the COVID-19 pandemic, many industries and systems such as the hospitality industry, education, the health industry, and many more, are facing various challenges. During this crisis, various technologies and innovative solutions were used in many industries. It was hoped that these system innovations play a role in reducing the threats posed by Coronavirus. Thus, the guest editors had invited submissions of papers that explore suggested or experienced solutions to the COVID-19 crisis; interested in original commentaries, case studies, empirical and conceptual papers from a wide range of topics. From thirteen received submissions, eight are published. 2 commentaries, 5 research articles, and 1 literature review could pass the peer-review process and be published. 23 authors from various countries (Bosnia and Herzegovina, Malaysia, Taiwan, Sweden, Italy, Germany, Iran, Indonesia, and Brone Darussalam) had input to these published works.

As of October 2021, the World Health Organization had received reports of near 250 million confirmed cases of COVID-19, with near 5 million deaths [1]. Quarantine and vaccination are approaches of limiting the spread of infection. Individuals who are suspected of having the disease or who have just returned from a risk region should be quarantined to restrict the spread of the virus. In a commentary in this special issue, Sorooshian [2] notes that in the absence of defined systematic procedures for nomination quarantine facilities, there are significant risks of lack of effectiveness, fraud, misuse, and unfairness. He additionally contains a list of methodical approaches that may be used for this sophisticated decision-making. Besides, in a separate report, Sorooshian et al. [3] concentrated on the COVID-19 vaccination program. Any failure on this mission will result in significant life and financial losses. So, the paper lays forward a framework of concerns that might lead to the failure of this mass vaccination campaign. They explored a system approach for the categorization of failure risks, comprising input, process, output, and feedback concerns. 
Additionally, one of the research articles [4] of this special issue, highlighted that the COVID-19 outbreak is among the world's worst disruptive, life-changing occurrences in the year 2020. The lock-downs and mobility restrictions enforced by the governments of several nations had a severe influence on schools and higher educational institutions. The school and the students were in virtual courses, many of them had to discover new things at rapid speed and feel a sense of despair without being aware of what they needed to accomplish. Although many Online Students experienced difficulties and worries about their experience of online learning, people had a chance to learn new things. The results of their research show that many students have a pleasant online learning experience and discovered that institutions have excellent Academic Continuity Plans. Some students have been concerned about online learning, including technological problems like inadequate internet connections and personal worries about academic ability and time management skills. The research closes with guides on how to effectively conduct online learning and teaching for everyone at institutions, teachers, and students.

Meanwhile another research article [5] of this special issue reports Integrated National Education Information System (iNEISTM). It was created to simplify and improve business operations, and to supply an education system application and technology platform for the pandemic COVID-19. The effect on end-users has been inadequate, such as lack of preparation for the organization's transformation and disorganized communication and sharing of information between stakeholders and end-users. The results showed an absence of beneficial effects on end-users, such as lack of preparedness and disorganized communication and information sharing between stakeholders and end-users to embrace organizational changes. This research suggests that if the stakeholder supplier and end-user are aware of the importance of the iNEISTM, the implementation can succeed in taking full use of the system.

Therefore, from the two research articles, information and communication (ICT) appeared to be a means for industry survival during the COVID-19. Benefits and barriers of ICT Adoption are also addressed in the published review article [6] from the point of view of the construction industry as an interaction between technology, task and a person from the standpoint of the industry. Even though potential merits of the deployment of ICT are clear, these advantages are not enough. Although both practitioners and researchers recognize ICT as an aggressive gain source, its existence alone would absolutely not ensure that the firm's ICT approval is achieved. Unless consumers are able to use the technology, companies cannot comprehend the full benefits of ICT. The challenges of ICT usage must thus be considered.

The use of digital technologies has beneficial effects on businesses during the COVID19 crisis, but several businesses raced into such digital transformation without adequate planning and giving sufficient attention to personnel matters. Thus, the focus of one of the research articles [7] published via this special issue was to offer improvements for a better digitization shift. As explained by the article, personnel well-being can be improved if industries are informed of essential steps such as coaching at a beginning period. So, as an outcome of the research, a software tool is presented by the authors and the tool is expected to assist industries in managing their complex project of digitization.

Moreover, another article [8] published via this special issue explaining that responding to a COVID-19 situation necessitates effective coordination and a multi-skilled approach (information, medical, statistical, social, political, and other skills), making it difficult to establish a single interface for everyone. According to the authors, a geoportal has been designed as an epidemiological location-intelligence system that facilitates the sharing of such information across entities and cantons. Their article discusses the detailed problems and solutions to the challenges in the creation and usage of the system.

Last but not least, this special issue also published a practice-based research [9]. This paper proposed a Leaning approach as an operative model for dealing with the COVID19 pandemic, so the authors aggregated data from the Lean model's implementation in an Emergency Department, the pandemic's epicenter, to critically assess its efficacy and 
feasibility. From the results, they report that the lean model has been shown to be beneficial in improving the overall treatment of COVID-19 patients in an emergency scenario. It enabled the screening of a large number of patients while simultaneously lowering the infection rate of health personnel.

The scope of this offered special issue raised the interest of practitioners and researchers, however, still, more can be learned from the experience of COVID-19. Hence future special issues are invited to continue addressing related topics including (but not limited to):

- Impacts of COVID-19 on different systems or industries;

- $\quad$ Role of modern technologies in addressing COVID-19 challenges;

- $\quad$ Readiness of systems and industries to use innovative technologies for managing COVID-19 effects;

- Any other innovative solutions to help systems and industries solve the challenges of COVID-19.

Funding: This research received no external funding.

Data Availability Statement: Not applicable.

Conflicts of Interest: The author declares no conflict of interest.

\section{References}

1. WHO Coronavirus (COVID-19) Dashboard. Available online: https:/ / covid19.who.int/ (accessed on 1 October 2021).

2. Sorooshian, S. Systematic Nomination of COVID-19 Quarantine Facilities. Appl. Syst. Innov. 2021, 4, 75. [CrossRef]

3. Sorooshian, S.; Abbaspour, A.; Jahan, A. A System View to the Risks of COVID-19 Vaccination Projects. Appl. Syst. Innov. 2022, 5, 20. [CrossRef]

4. Rasiah, R.; Kaur, H.; Guptan, V. Business continuity plan in the higher education industry: University students' perceptions of the effectiveness of academic continuity plans during COVID-19 pandemic. Appl. Syst. Innov. 2020, 3, 51. [CrossRef]

5. Ibrahim, F.; Susanto, H.; Haghi, P.K.; Setiana, D. Shifting paradigm of education landscape in time of the COVID-19 pandemic: Revealing of a digital education management information system. Appl. Syst. Innov. 2020, 3, 49. [CrossRef]

6. Moshood, T.D.; Nawanir, G.; Sorooshian, S.; Mahmud, F.; Adeleke, A.Q. Barriers and benefits of ICT adoption in the nigerian construction industry. a comprehensive literature review. Appl. Syst. Innov. 2020, 3, 46. [CrossRef]

7. Eickemeyer, S.C.; Busch, J.; Liu, C.-T.; Lippke, S. Acting Instead of Reacting-Ensuring Employee Retention during Successful Introduction of i4.0. Appl. Syst. Innov. 2021, 4, 97. [CrossRef]

8. Karabegovic, A.; Ponjavic, M.; Hukic, M. Epidemic Location Intelligence System as Response to the COVID-19 Outbreak in Bosnia and Herzegovina. Appl. Syst. Innov. 2021, 4, 79. [CrossRef]

9. Desai, A.; Goretti, G.; Giordano, M.; Voza, A. Lean-ing Method in an Emergency Department of the Italian Epicenter of the COVID-19 Outbreak: When the Algorithm Makes Difference. Appl. Syst. Innov. 2021, 4, 55. [CrossRef] 